\title{
PEMAHAMAN KONSEP TASAMUH (TOLERANSI) SISWA DALAM AJARAN ISLAM
}

\begin{abstract}
Ahmad Sholeh ${ }^{1}$
Abstract

This article focuses on the understanding "tasamuh" concept by the students in the learning Islamic. This article is the result of research that using quantitative method, while to get the data using collecting data technique: observation, questionnaire, and documentation. The result of this research shows that: First, variable of Qur'an-Hadith lesson has contribution to understanding "tasamuh" concepts by the students significantly. This is evidenced by the result of SPSS analysis for windows with significance level $p=0,042$ and in the partial analysis the contribution is 4,9\%. Second, variable of Qur'an-Hadith lesson has contribution to understanding "tasamuh" concepts by the students significantly. This is evidenced by the result of SPSS analysis for windows with significance level $p=0,012$ and in the partial analysis the contribution is 6,9\%. Third, variable of Qur'an-Hadith lesson do not have contribution to understanding "tasamuh" concept by the students significantly. This is evidenced by the result of SPSS analysis for windows with significance level $p=0,469$ and in the partial analysis the contribution is $0,7 \%$. Fourth, based on the result of double regression analysis use SPSS for window was obtained determinant coefficient $R^{2}=0,117 ; p=0,009$. Its mean $12 \%$ variation of variable of understanding "tasamuh" concept of the students influenced by Al-Qur'an Hadith lesson, Aqidah Akhlak, and Fiqh at the same time. The rest are influenced by other variable beside the variable of Al-Qur'anHadith, Aqidah Akhlak, and Fiqh.
\end{abstract}

Keywords: Understanding, Tasamuh, Contribution

\section{A. Pendahuluan}

Bergulirnya era reformasi mengharuskan seluruh masyarakat Indonesia untuk tetap menegakkan persatuan bangsa. Oleh karena itu, hal ini menjadi dasar adanya pembangunan dibidang agama, terutama yang berkaitan dengan sikap tasamuh atau toleransi umat Beragama. Sikap tasamuh yang

1 Dosen Fakultas Ilmu Tarbiyah Dan Keguruan Universitas Islam Negeri Maulana Malik Ibrahim Malang Jl. Gajayana No. 50 Malang 65144 
harus dipegang menurut Harun Nasution (Usa, 1997:126) yang menjadi dasar penyusunan konsep teologi kerukunan, yakni 1). Mencoba melihat kebenaran yang ada pada agama lain, 2). Memperkecil perbedaan di antara agama-agama, 3). Menonjolkan persamaan yang ada dalam agama, 4). Menghimpun rasa persaudaraan setuhan, 5). Memusatkan usaha pada pembinaan individu dan masyarakat yang baik, yang menjadi tujuan beragama dari semua agama monotheism, 6). Mengutamakan pelaksanaan ajaran-ajaran yang membawa kepada toleransi beragama dan 7). Menjauhi praktek serang menyerang antar agama.

Upaya internalisasi konsep tersebut secara sistematis dilakukan melalui lembaga pendidikan dengan memasukannya dalam kurikulum. Imam Mujono mengatakan bahwa, upaya menjaga kerukunan antar umat beragama tidak dapat dilakukan dengan sambil lau saja, apalagi hanya bersifat koratif dan temporer. Upaya itu harus lebih bersifat prefentif kontemporer. Pemantapan toleransi segenap bangsa secara sistematis dapat direalisasikan melalui pendidikan sekolah yakni melalui pendidikan agama (Usa,1997:126).

Kita bisa belajar dari sejarah Islam yang menunjukkan begitu tolerannya umat Islam terhadap non-Islam. Muhammad bin al-Hasan murid imam Abu Hanifah pernah meriwayatkan bahwa Rasulullah saw pernah mengirim harta benda ke penduduk Makkah ketika mereka dilanda bahaya kelaparan untuk dibagi-bagikan kepada orang-orang fakir mereka. Padahal penduduk Makkah pada waktu itu sikapnya sangat kejam dan sangat menentang Rasulullah dan pengikutnya. Begitu tolerannya Rasulullah Saw.

Contoh lain tentang perlakuan Islam terhadap non-Islam adalah kemurahan hati yang diperlihatkan oleh Salahuddin al-Ayyubi pada tahun 1188 M saat dia berhasil merebut kembali Yerussalem dari tentara salib. Ketika Salahuddin tiba ia menyaksikan pasukan salib sedang mengotori masjid dengan menyimpan babi di dalamnya. Bahkan para ahli sejarah Eropa pun mengakui bahwa Salahuddin tidak membalas dendam, melainkan memberikan maaf kepada pasukan salib, dengan pengecualian segelintir individu yang memang berprilaku sadis dan kejam (Muhammad Abdul Halim, Understanding Quran: themes and style). Hari ini, Islam dicurigai sebagai agama yang tidak toleran. Hari ini makna toleran juga telah disalah artikan sehingga akhirnya agama menjadi objek permainan. Tugas bersama 
bagi kita adalah memahamkan kembali tentang konsep toleransi dalam Islam secara benar.

Di sinilah peran pendidikan Islam sangat penting dalam memahamkan akan pentingnya arti makna tasamuh dalam ajaran Islam sehingga akan mewujudkan persatuan dan kesatuan di antara sesama bangsa. Hal ini terutama berkaiatan dengan mata pelajaran alqur’an hadits, Aqidah Akhlak dan Feqh. Karena ketiga-tiganya merupakan wahana untuk mengembangkan dan melestarikan nilai-nilai luhur dan moral umat manusia yang diwujudkan dalam bentuk perilaku dalam kehidupan sehari-hari peserta didik, baik sebagai individu maupun sebagai anggota masyarakat dan mahluk ciptaan Allah SWT.

Namun pada kenyataannya, mata pelajaran ini (al-Qur`an Hadits, Aqidah Akhlak dan Feqh) kurang diberikan dalam bentuk latihan pengalaman untuk menjadi corak kehidupan sehari-hari. Karenanya para siswa di madrasah cendrung tidak memiliki kepekaan yang cukup untuk membangun toleransi (tasamuh), kebersamaan khususnya akan adanya masyarakat yang majemuk. Atau dengan kata lain keberadaan mata pelajaran ini kurang mempunyai kontribusi terhadap pengembangan pribadi dan watak peserta didik. Hal ini disebabkan proses pembelajarannya belum sepenuhnya dilaksanakan pendekatan siswa aktif. Sementara metode ceramah dan Tanya jawab masih digunakan sangat dominan. Ini berarti kurangnya komunikasi antar warga sekolah yang bersifat terbuka dengan dialog secara akrab.

Kenyataan di atas sesuai dengan apa yang dikatakan Madjid,(1997:141) bahwa pengajaran agama disekolah dan madrasah umumnya didominasi oleh orientasi lahiriyah, Feqh dan kalam, yaitu segi-segi eksoteris. Oleh karenanya anak didik hanya faham tentang rukun dan syarat sholat bukan kepada untuk mengetahui apa makna sesungguhnya sholat bagi pembentukan karakter seseorang. Kurang diajarkannya berbagai macam pendapat dalam masalah furuiyah sehingga hanya menimbulkan fanatisme yang berlebihan dan mengakibatkan kurangnya sikap toleran (tasamuh) dalam kehidupan bersama. Oleh karena itulah maka peneliti disini akan mencoba mengkaji tentang bagaimana kontribusi mata pelajaran di atas terhadap pemahaman siswa tentang konsep tasamuh dalam Islam dengan mengambil studi di MTs al-Ma`arif Singosari dan MTsN I Lawang Malang. 


\section{B. Rumusan Masalah}

Berdasarkan latar belakang diatas, maka rumusan masalah dalam penelitian ini dapat dirumuskan sebagai berikut:

a. Manakah diantara mata pelajaran al-Qur`an Hadits, Aqidah Akhlak dan Feqh yang mempunyai kontribusi terbesar terhadap pemahaman siswa tentang konsep tasamuh dalam Islam?

b. Seberapa besar kontribusi mata pelajaran al-Qur`an Hadits, Aqidah Akhlak dan Feqh secara bersama-sama terhadap pemahaman siswa tentang konsep tasamuh dalam Islam?

\section{Tujuan Penelitian}

Penelitian ini bertujuan untuk mengetahui :

1. Kontribusi mata pelajaran al-Qur`an Hadits terhadap pemahaman siswa tentang konsep tasamuh dalam Islam.

2. Kontribusi mata pelajaran Aqidah Akhlak terhadap pemahaman siswa tentang konsep tasamuh dalam Islam.

3. Kontribusi mata pelajaran Feqh terhadap pemahaman siswa tentang konsep tasamuh dalam Islam.

4. Kontribusi mata pelajaran al-Qur`an Hadits, Aqidah Akhlak dan Feqh secara bersama-sama terhadap pemahaman siswa tentang konsep tasamuh dalam Islam.

\section{Manfaat Penelitian}

Secara keilmuan, penelitian ini akan menambah wawasan pengetahuan tentang konsep-konsep dasar tentang pendidikan khususnya yang berkaiatan tentang pemahaman siswa tentang konsep tasamuh dalam Islam. Di samping itu akan dikembangkannya instrument yang dapat mengukur tentang pemahaman siswa tentang konsep tasamuh tersebut. Namun secara praktis, penelitian ini akan memberikan kontribusi dalam memberikan gambaran informatif yang akurat tentang penanaman tentang konsep tasamuh terhadap peserta didik.

Secara lebih khusus, penelitian ini akan berguna untuk: 
1. Para guru agama Islam di MTs al-Ma`arif Singosari dan MTsN I Lawang akan memperoleh gambaran tentang sejauh mana kontribusi mata pelajaran al-Qur`an Hadits, Aqidah Akhlak dan Feqh terhadap pemahaman siswa tentang konsep tasamuh.

2. Sebagai dasar penyusunan program perbaikan di bidang pendidikan terutama dalam mengembangkan penanaman dan pemahaman tentang konsep tasamuh dalam Islam untuk peserta didik.

\section{E. Penelitian Terdahulu yang Relevan}

Ada beberapa penelitian yang yang relevan dengan permasalahan ini di antaranya adalah penenelitian Ajat maupun Choliq Muchtar (1994). Namun penelitian ini menggunakan pendekatan kualitatif dan menyimpulkan bahwa konsep kerukunan yang paling tepat di masyarakat adalah konsep "agree in disagreement". Di samping itu ada penelitiannya Asnafiyah (2002) yang menyimpulkan bahwa mata pelajaran agama Islam di SMU Yogyakarta mempunyai kontribusi terbesar terhadap sikap toleransi beragama siswa dibanding dengan mata pelajaran PPKn dan sosiologi.

Berdasarkan beberapa penelitian yang relevan di atas, maka penelitian ini dapat dikatakan berbeda dengan penelitian-penelitian yang sudah ada. Karena penelitian ini mencoba secara spesifik dan mendalam akan mengkaji bagaimana pola pemahaman siswa terhadap konsep tasamuh dalam Islam baik tasamuh/tolerasi sesama muslim maupun dengan non muslim serta mengkaji secara mendalam bagaimana kontribusi mata pelajaran al-Qur`an Hadits, Aqidah Akhlak dan Feqh yang diajarkan di MTs terhadap pemahaman siswa tentang konsep tasamuh dengan pendekatan kuantitatif.

\section{F. Kajian Teori dan Kerangka Berfikir}

\section{Konsep Tasamuh dalam Islam}

Dalam mengkaji isu toleransi dalam Islam, kita menemukan sebuah situasi yang sama sekali sangat berbeda. Hal itu adalah tidak ada kata bahasa Arab yang sepadan untuk mengartikan apa yang secara tradisional dipahami sebagai "tolerance" (toleransi) dalam bahasa Inggris. Kata yang 
dipergunakan untuk mendekatkan kata toleransi ini adalah tasamuh, yang telah menjadi istilah mutakhir bagi toleransi. Bentuk akar dari kata ini mempunyai dua macam konotasi: "kemurahan hati" (Jud wa karam) dan "kemudahan" (tasahul). Karena itu, kaum muslimin berbicara tentang tasamuh al-Islam dan tasamuh al-dini sangat berbeda dengan toleransi yang dipahami oleh Barat.

Di Barat kata "toleransi" itu menunjukkan adanya sebuah otoritas berkuasa, yang dengan enggan bersikap sabar atau membiarkan orang lain yang berbeda. Namun, dalam Islam kata "tasamuh" yang menjembatani kata toleransi justru menunjukkan kemurahan hati dan kemudahan dari kedua belah pihak atas dasar saling pengertian. Istilah itu selalu dipergunakan dalam bentuk resiprokal (hubungan timbal balik). Dengan demikian toleransi dalam Islam bisa dimaknakan membangun sikap untuk saling menghargai, saling menghormati antara satu dengan lainnya.

Setidak-tidaknya ada dua macam tasamuh. Pertama, tasamuh antar sesama manusia muslim yang berupa sikap dan perilaku tolong menolong saling menghargai, saling menyayangi, saling menasehati, dan tidak curiga mencurigai. Kedua, tasamuh terhadap manusia non muslim, seperti menghargai hak-hak mereka selaku manusia dan anggota masyarakat dalam satu negara. Dengan kata lain, toleransi didasarkan atas prinsipprinsip: 1. bertetangga baik; 2 . saling membantu dalam menghadapi musuh bersama; 3. membela mereka yang teraniaya; 4. Saling menasehati, dan 5. menghormati kebebasan beragama.

Untuk mengembangkan sikap toleransi (tasamuh) secara umum, dapat kita mulai terlebih dahulu dengan bagaimana kemampuan kita mengelola dan mensikapi perbedaan (pendapat) yang (mungkin) terjadi pada keluarga kita atau pada keluarga/saudara kita sesama muslim. Sikap toleransi dimulai dengan cara membangun kebersamaan atau keharmonisan dan menyadari adanya perbedaan. Dan menyadari pula bahwa kita semua adalah bersaudara. Maka akan timbul rasa kasih saying, saling pengertian dan pada akhirnya akan bermuara pada sikap toleran. Dalam konteks pendapat dan pengamalan agama, al-Qur'an secara tegas memerintahkan orang-orang mu'min untuk kembali kepada Allah (al-Qur'an) dan Rasul (sunnah) (M. Quraish Syihab :1997:89).

Dalam kaitannya dengan toleransi antar umat beragama, toleransi 
hendaknya dapat dimaknai sebagai suatu sikap untuk dapat hidup bersama masyarakat penganut agama lain, dengan memiliki kebebasan untuk menjalankan prinsip-prinsip keagamaan (ibadah) masing-masing, tanpa adanya paksaan dan tekanan, baik untuk beribadah maupun tidak beribadah, dari satu pihak ke pihak lain. Hal demikian dalam tingkat praktek-praktek social dapat dimulai dari sikap bertetangga, karena toleransi yang paling hakiki adalah sikap kebersamaan antara penganut keagamaan dalam praktek social, kehidupan bertetangga dan bermasyarakat, serta bukan hanya sekedar pada tataran logika dan wacana.

Dalam bukunya Psikologi Agama, Jalaluddin Rakhmat (Ridlwan Ruswandi: 2011) menggambarkan lima dimensi kehidupan beragama. Kelima dimensi tersebut ialah : dimensi kepercayaan, dimensi intelektual, dimensi mistikal, dimensi ekspresialitas, dan dimensi sosial.

Dimensi kepercayaan, adalah semacam gambaran tentang kepercayaan para penganutnya. Dalam islam dimensi ini tercermin dari makna Syahadat yang merupakan kalimah Tauhid. Setidaknya dalam kalimat tauhid terdapat dua penegasan bagi kita. Pertama, merupakan penegasan kesaksian manusia terhadap Allah yang telah menciptakan manusia dan segala kehidupannya. Firman Allah dalam surat Al-a'raf ayat 172, dimana dalam hal ini Allah menggambarkan kesaksian manusia akan keagungan Tuhan. Dalam bahasa Nurcholish Madjid, ungkapan Tuhan dalam ayat tersebut lazim dikenal dengan janji primordial manusia.kedua, penegasan manusia bahwa tiada Tuhan yang patut di sembah selain Tuhan semesta Alam, Allah SWT.

Dimensi Intelektual, dimensi logika. Dimana dimensi ini mengharuskan para penganut agama tertentu untuk tidak menerima segala sesuatu secara taken for granted. Segala sesuatu yang diperintahkan harus melalui seganap proses yang panjang. Proses pemikiran yang benar-benar akan mengantarkan manusia pada keyakinan yang sesuai dengan akal dan dapat dirasakan oleh perasaan. Manusia dibubuhi akal, maka dengan akal tersebut manusia diharuskan untuk senantiasa memahami segenap pemikiran yang ada secara kritis dan dinamis.

Dimensi ekspresialitas, dimensi yang mencerminkan sebuah agama secara nyata. Dimensi ini mengharuskan penganutnya mengaplikansikan berbagai konsepsi hidup yang ditawarkan oleh suatu agama dalam kehidupan nyata. Konsepsi yang dilakukan haruslah mendatangkan implikasi 
yang positif dalam kehidupan kita. Dalam islam misalnya diperintahkan melakukan shalat, zakat, puasa, haji, infak, dll.

Dimensi Mistikal, semacam keyakinan kita terhadap hal-hal diluar alam nyata. Kepercayaan kita akan adanya sesuatu yang tidak terpikirkan secara logika. Misalnya akan adanya kehidupan akhirat, surga, neraka, hari baats, alam barzah, kiamat, dll.

Dimensi social, merupakan dimensi yang paling penting. Dimensi social ini yang kemudian menjadi pijakan awal bagi kita untuk senantiasa menghargai perbedaan yang tercipta di antara manusia. Dimensi social ini yang menjadi konsepsi hidup kita dalam menjalani kehidupan social. Dimensi ini pula mencoba menggambarkan tata hubungan social kemasyarakatan yang harus dijalankan demi terciptanya kehidupan yang sesuai dengan apa yang diaharapkan. Kelima dimensi tersebut merupakan sesuatu yang harus dikedepankan dalam kehidupan kita, terutama ketika kita dihadapkan pada realitas kehidupan beragama yang berbeda dalam segala hal. Dan hal ini pula yang akan mengantarkan kita pada konsepsi tasamuh atau toleransi dalam kehidupan beragama.

Dr. Syekh Yusuf al-Qaradhawi (Fahmi Salim ; 2008) menyebutkan empat faktor yang melahirkan sikap toleransi yang unik selalu mendominasi perilaku umat Islam terhadap non-muslim: Pertama, keyakinan terhadap kemuliaan manusia, apapun agamanya, kebangsaan dan kesukuannya. Kemuliaan ini mengimplikasikan hak untuk dihormati. Kedua, kayakinan bahwa perbedaan manusia dalam agama dan keyakinan merupakan realitas (ontologis) yang dikehendaki Allah SWT yang telah memberi mereka kebebasan untuk memilih iman atau kufur. Oleh karenanya tidak dibenarkan memaksa mereka untuk Islam. Ketiga, seorang muslim tidak dituntut untuk mengadili kekafiran orang kafir atau menghukum kesesatan orang sesat. Allah SWT lah yang akan mengadili mereka di hari perhitungan kelak. (al-Hajj: 69, al-Syura: 15) Dengan demikian hati seorang muslim menjadi tenang, tidak perlu terjadi konflik batin antara kewajiban berbuat baik dan adil kepada mereka (al-Mumtahanah: 8), dan dalam waktu yang sama harus berpegang teguh pada kebenaran keyakinannya sendiri. Keempat, keyakinan bahwa Allah SWT memerintahkan untuk berbuat Adil dan mengajak kepada budi pekerti mulia meskipun kepada orang musyrik (at-Tawbah: 6). Begitu juga Allah SWT mencela perbuatan zalim 
meskipun terhadap orang kafir (al-Maidah: 8).

Sedang menurut Kharis Nugroho (2011) dalam Islam, toleransi (Tasamuh) merupakan ciri khas dari ajaran Islam. Ketoleranan Islam mencakup berbagai segi, baik dari segi akidah, ibadah, maupun muamalah. Dari segi aqidah, Islam mempunyai kaidah dari sebuah ayat Al-Qur'an yaitu laa ikraaha fi al-dien (tidak ada paksakan dalam agama). Namun kaidah ini tidak menafikan unsur dakwah dalam Islam. Dakwah dalam Islam bersifat mengajak, bukan memaksa. Dari kaidah inilah maka ketika non-muslim (khususnya kaum dzimmi) berada di tengah-tengah umat Islam atau di negara Islam, maka mereka tidak boleh dipaksa masuk Islam bahkan dijamin keamanannya karena membayar jizyah sebagai jaminannya.

Dalam masalah Ibadah, Islam juga bersifat toleran. Maksudnya, pelaksanaan ibadah di dalam Islam bersifat tidak membebani. Hal tersebut bisa kita lihat ketika seseorang ingin berwudhu dan tidak ada air, maka Islam mempermudah cara berwudhu dengan cara tayamum. Di dalam shalat, ketika seseorang tidak mampu berdiri, maka boleh dengan duduk. Begitu juga puasa, ketika seseorang sedang sakit, maka boleh di qadha. Sifat mempermudah dan tidak membebankan seseorang inilah yang menjadi ciri khas bahwa Islam adalah agama yang toleran dari segi ibadah.

Adapun dalam muamalah, Islam menyuruh berbuat baik dalam bermasyarakat, baik itu kepada yang muslim atau non-muslim. Misalnya, ketika seorang muslim mempunyai tetangga non-muslim yang sedang membutuhkan bantuan, maka harus dibantu. Ketika diberi hadiah, maka harus diterima. Begitu juga ketika ada tetangga non-muslim sedang sakit, harus dijenguk. Itulah adab seorang muslim yang harus dijaga dalam rangka membangun kerukunan antar umat beragama.

\section{Al-Qur`an Hadits}

Al Qur'an Hadis merupakan unsur mata pelajaran Agama Islam pada madrasah yang memberikan pemahaman kepada peserta didik tentang Al-Qur'an dan Hadits sebagai sumber ajaran agama Islam.

Mata pelajaran Al-Qur'an dan Hadits pada madrasah memiliki fungsi sebagai berikut: 
a) Pengembangan, yaitu meningkatkan keimanan dan ketaqwaan peserta didik dalam meyakini kebenaran ajaran Islam yang telah dimulai dan dilaksanakan dalam lingkungan keluarga maupun jenjang pendidikan sebelumnya.

b) Perbaikan, yaitu memperbaiki kesalahan dalam keyakinan, pemahaman dan pengalaman ajaran Islam peserta didik dalam kehidupan sehari-hari.

c) Pencegahan, yaitu untuk menangkal hal-hal negatif dari lingkungan atau budaya lain yang dapat membahayakan diri peserta didik dan menghambat perkembangannya menuju manusia Indonesia seutuhnya yang beriman dan bertaqwa kepada Allah SWT.

d) Pembiasaan, yaitu menjadikan nilai-nilai Al-Qur'an dan Al-Hadits sebagai petunjuk dan pedoman bagi peserta didik dalam kehidupannya sehari-hari.(Departemen Agama RI, 1994:5.)

\section{Aqidah Akhlak}

Aqidah berasal dari bahasa Arab aqoda-ya' taqidu-I'tiqodan, yang memiliki arti yakin, menyakini dan keyakinan. Sedangkan menurut istilah Aqidah adalah suatu perkara yang wajib dibenarkan (dipercaya) oleh hati dengan penuh kemantapan atau keyakinan dalam kalbu (jiwa), sehingga terhindar dari keraguan-keraguan. Aqidah dapat juga disebut dengan iman (kepercayaan).

Menurut Hasan Al Banna disebutkan bahwa aqidah adalah beberapa perkara yang wajib diyakini kebenarannya oleh hati yang dapat mendatangkan ketentraman jiwa, menjadikan keyakinan yang tidak tercampur sedikitpun dengan keraguan-keraguan. (Yuhanar Ilyas 1992:1)

Akhlak berasal dari bahasa Arab “ Akhlak” dengan bentuk jama' "khuluq" yang berarti budi pekerti. Secara istilah akhlak adalah sistem nilai yang mengatur pola sikap dan tindakan manusia diatas bumi. Dan sistem nilai yang dimaksud adalah ajaran Islam dengan Al-Qur'an dan As-Sunnah Rasul sebagai sumber nilai dan serta ijtihad sebagai metode berfikir Islami. (Zahruddin AR, dan Hasanuddin Sinaga, 2004:3) 
Al-Ghazali dalam kitabnya Ihya' Ulumudin mendefinisikan bahwa akhlak adalah gambaran tingkah laku dalam jiwa dari padanya lahir perbuatan-perbuatan dengan mudah tanpa memerlukan pemikiran dan pertimbangan. Sedangkan Ahmad Amin memberikan definisi bahwa akhlak adalah a'datul atau kehendak yang membiasakan artinya kehendak itu bila membiaskan sesuatu, maka kebiasaan itulah yang dinamakan dengan akhlak. (Romli Arief, tt:119)

Aqidah Akhlak merupakan pembelajaran penting bagi setiap manusia dalam proses pendidikan, dengan tujuan Aqidah Akhlak yang pernah dipelajari dapat menjadi pedoman hidup dalam rangka menyempurnakan Iman.

Adapun karakteristik Aqidah Akhlak pada Madrasah Tsanawiyah dalam pedoman khusus Aqidah Akhlak Depag antara lain:

1. Prinsip-prinsip dasar Aqidah akhlak adalah kepercayaan atau keyakinan yang tersimpul dan terhujam kuat di dalam lubuk jiwa (hati) manusia dengan dalil naqli, aqli dan wijdani (perasaan halus) dalam meyakini dan mewujudkan rukun iman. Akhlak adalah pembentukan sikap dan kepribadian seseorang untuk berakhlak mulia (Akhlaq Al-Mahmudah) dan mengeliminasi akhlak tercela (Akhlak Al-Madzmumah) sebagai manifestasi aqidahnya dalam perilaku hidup seseorang dalam berakhlak kepada allah SWT dan Rasul-Nya, kepada diri sendiri, kepada sesama manusia, dan kepada alam dan makhluk lain.

2. Mata pelajaran Aqidah dan Akhlak merupakan salah satu rumpun mata pelajaran agama di Madrasah (Al-Qur'an dan Hadits, Aqidah dan Akhlak, syariah/fiqih, Sejarah kebudayaan Islam) yang secara integratife menjadi sumber nilai dan landasan moral spiritual yang kokoh dalam pengembangan keilmuan dan keislaman, termasuk kajian yang terkait dengan ilmu dan teknologi serta seni dan budaya.

3. Mata pelajaran Aqidah Akhlak tidak hanya mengantarkan siswa untuk menguasai pengetahuan tentang Aqidah dan Akhlak, tetapi yang terpenting adalah bagaimana siswa dapat mengamalkan Aqidah dan Akhlak dalam kehidupam sehari-hari. Mata pelajaran Aqidah dan 
Akhlak menekankan keutuhan dan keterpaduan antara pengetahuan dan sikap, dan perilaku atau lebih menekankan pembentukan ranah afektif dan psikomotorik dan dilandasi oleh ranah kognitif.

4. Pendidikan Aqidah Akhlak merupakan mata pelajaran yang dikembangkan dari ajaran-ajaran dasar yang terdapat dalam agama Islam yang bersumber pada $\mathrm{Al}-\mathrm{Qur}$ 'an dan $\mathrm{Al}$-Hadits.

5. Tujuaan mata pelajaran Aqidah Akhlak adalah untuk membentuk siswa beriman dan bertaqwa pada Allah SWT. Dan memiliki akhlak mulia dan tujuan inilah yang sebenarnya misi utama diutusnya nabi Muhammad SAW. Pendidikan Aqidah Akhlak merupakan jiwa pendidikan agama Islam. Dengan demikian membentuk Akhlak yang mulia sesungguhnya merupakan tujuan pendidikan. Sejalan dengan tujuan inti maka semua mata pelajaran atau bidang studi yang diajarkan pada peserta didik haruslah mengandung pendidikan akhlak dan setiap guru mengemban misi membangun akhlak dan tingkah laku siswanya.

Adapun kompetensi mata pelajaran Aqidah Akhlak di Madrasah Tsanawiyah adalah sebagai berikut:

1. Memahami dasar dan tujuan Aqidah Islam serta mampu menganalisa secara ilmiah hubungan dan implementasinya dalam kehidupan sehari-hari

2. Meningkatkan keimanan kepada Allah melalui pemahaman sifatsifat-Nya serta mampu menganalisa secara ilmiah dan terbiasa berakhlak terpuji (Ikhlas, Taat, Khauf, dan Taubat dan menghindari akhlak tercela Riya'dan Nifaq dalam kehidupan sehari-hari.

3. Memahami dan meyakini kebenaran kitab-kitab Allah serta mampu menganalisis secara ilmiah dan terbiasa berakhlak terpuji kepada diri sendiri Tawakal, Ikhtiyar, Sabar, Syukur, Qonaah dan menghindari akhlak tercela Ananiah, Putus asa, Ghadab, Tamak, Takabur dalam kehidupan sehari-hari.

4. Memahami dan meyakini hakikat iman kepada Rasul serta memahami mukjizat dan kejadian luar biasa lainnya (Karamah, Ma'unah, Irsh) serta mampu terbiasa berakhlak mulia (Husnuzhan, Tawadhu', Tasamuh, Ta'awun) dan menghindari akhlak tercela 
(Hasad, Dendam, Ghibah, Fitnah dan Namimah) dalam kehidupan sehari-hari.

5. Memahami dan meyakini hakikat beriman kepada hari akhir dan alam ghaib yang masih berhubungan dengan hari akhir serta mampu menganalisis secara ilmiah dan terbiasa berakhlak terpuji terhadap diri sendiri (Berilmu, Kerja Keras, Kreatif dan Produktif) dalam kehidupan sehari-hari.

6. Memahami dan meyakini hakikat beriman kepada Qada dan Qadar serta mampu menganalisis secara ilmiah dan menerapkan akhlak terpuji dalam pergaulan remaja. (Departemen Agama RI, 2004: 34)

\section{Mata Pelajaran Feqh}

Mata pelajaran Feqh dalam Kurikulum Madrasah Tsanawiyah adalah salah satu bagian mata pelajaran Pendidikan Agama Islam yang diarahkan untuk menyiapkan peserta didik untuk mengenal, memahami, menghayati dan mengamalkan hukum Islam yang kemudian menjadi dasar pandangan hidupnya (way of life) melalui kegiatan bimbingan, pengajaran, latihan penggunaan, pengamalan dan pembiasaan.

Mata pelajaran Feqh Madrasah Tsanawiyah ini meliputi : Feqh Ibadah, Feqh Muamalah, Feqh Jinayat dan Feqh Siyasah yangmenggambarkan bahwa ruang lingkup Feqh mencakup perwujudankeserasian, keselarasan, dan keseimbangan hubungan manusia dengan43Allah SWT., dengan diri sendiri, sesama manusia, makhluk lainnya, maupun lingkungannya (hablun minallah wa hablun minannaas).

Pembelajaran Feqh di Madrasah Tsanawiyah bertujuan untuk membekali peserta didik agar dapat: (1) mengetahui dan memahami pokok-pokok hukum Islam secara terperinci dan menyeluruh, baik berupa dalil naqli dan aqli. Pengetahuan dan pemahaman tersebut diharapkan menjadi pedoman hidup dalam kehidupan dan sosial. (2) Melaksanakan dan mengamalkan ketentuan hukum Islam dengan benar. Pengalaman tersebut diharapkan menumbuhkan ketaatan menjalankan hukum Islam, disiplin dan tanggung jawab sosial yang tinggi dalam kehidupan pribadi maupun sosial. 
Pembelajaran Feqh di Madrasah Tsanawiyah berfungsi untuk: (a) Penanaman nilai-nilai dan kesadaran beribadah peserta didik kepada Allah Swt. sebagai pedoman mencapai kebahagiaan hidup di dunia dan akhirat; b) Penanaman kebiasaan melaksanakan hukum Islam di kalangan peserta didik dengan ikhlas dan perilaku yang sesuai dengan peraturan yang berlaku di madrasah dan masyarakat; (c) Pembentukan kedisiplinan dan rasa tanggung jawab sosial di Madrasah dan masyarakat; (d) Pengembangan keimanan dan ketaqwaan kepada Allah. Swt. serta akhlaq mulia peserta didik seoptimal mungkin, melanjutkan yang telah ditanamkan lebih dahulu dalam lingkungan keluarga; (d) Pembangunan mental peserta didik terhadap lingkungan fisik dan sosial melalui ibadah dan muamalah; (e) Perbaikan kesalahan-kesalahan, kelemahan-kelemahan peserta didik dalam keyakinan dan pelaksanaan ibadah dalam kehidupan sehari-hari; (f) Pembekalan peserta didik untuk mendalami Feqh/hukum Islam pada jenjang pendidikan yang lebih tinggi.

Sedangkan Ruang Lingkup Mata Pelajaran Feqh di Madrasah Tsanawiyah meliputi keserasian,keselarasan, dan keseimbangan antara:

- Hubungan manusia dengan Allah Swt.

- Hubungan manusia dengan sesama manusia, dan

- Hubungan manusia dengan alam (selain manusia) dan lingkungan.

\section{Kerangka berfikir dan Hipotesis}

Asumsi yang mendasari pengajuan permasalahan yang akan diteliti adalah pemahaman seseorang terhadap suatu objek ditentutan baik oleh factor internal maupun eksternal. Pembelajaran yang diberikan kepada siswa berpengaruh terhadap pemahaman dan sikap tasamuh siswa. Dengan demikian kerangka paradigma penelitiannya sebagai berikut:
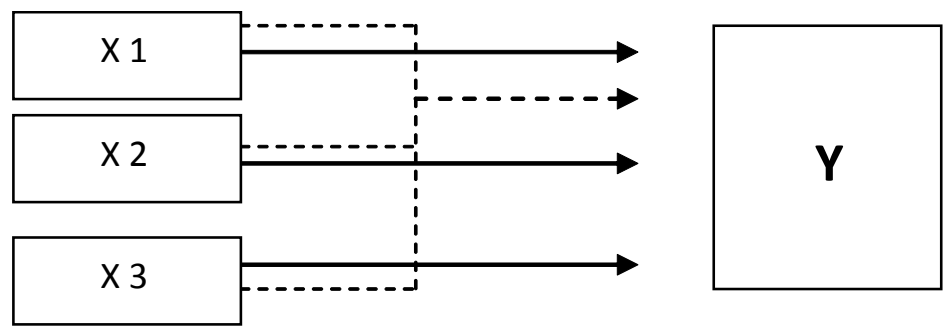
Ket: X1 = mata pelajaran al-Qur`an Hadits

X2 = Aqidah Akhlak

$\mathrm{X} 3=$ Feqh

$\mathrm{Y}=$ Pemahaman konsep tasamuh siswa

Berdasarkan paradigma kerangka di atas dapat diajukan hipotesis penelitian sebagai berikut:

1. Ada kontribusi yang signifikan mata pelajaran al-Qur`an Hadits terhadap pemahaman siswa terhadap konsep tasamuh dalam Islam.

2. Ada kontribusi yang signifikan mata pelajaran Aqidah Akhlak terhadap pemahaman siswa terhadap konsep tasamuh dalam Islam.

3. Ada kontribusi yang signifikan mata pelajaran Feqh terhadap pemahaman siswa terhadap konsep tasamuh dalam Islam.

4. Ada kontribusi yang signifikan mata pelajaran al-Qur’an Hadits, Aqidah Akhlak dan Feqh secara bersama-sama terhadap pemahaman siswa terhadap konsep tasamuh dalam Islam.

\section{G. Metodologi Penelitian}

\section{Tempat dan Waktu}

Penelitian ini akan dilaksanakan di MTs al-Ma`arif Singosari dan MTsN I Lawang Malang. Sedang waktu pelaksanaan penelitian ini dilakukan selama 2 bulan terhitung setelah proposal ini diterima untuk diteruskan studi di lapangan.

\section{Jenis Penelitian dan Defenisi Operasional}

Jenis penelitian ini adalah penelitian survey yang bersifat Ex Post Facto. Karena akan meliwati peristiwa-peristiwa yang telah terjadi dan merunutnya ke belakang untuk menemukan factor-faktor yang mendahuluinya atau menentukan sebab-sebab yang mungkin dapat menjelaskan peristiwaperistiwa yang akan diteliti (sugiono, 1997:3).

Dalam hal ini peneliti tidak perlu memanipulasi variable-variabel yang ada, karena variable-variabel tersebut telah ada dalam setting yang 
natural. Dengan demikian peneliti akanmencoba menentukan hubungan dan pengaruh yang terjadi diantara variable-variabel yang ada. Penelitian ini mengkaji perlakuan variable bebas $(\mathrm{X}$ ) yang telah terjadi sebelumnya, peneliti tidak mengkontrol variable bebas sebab peneliti tidak memberikan perlakuan apapun. Melalui penelitian ini dilakukan penelaahan terhadap keadaan yang sedang ada pada diri subjek.

Adapun operasional dari beberapa variable adalah sebagai berikut:

a. Pemahaman konsep tasamuh siswa dalam Islam adalah kemampuan siwa dalam memahami tentang kebebasan orang lain, menghormati orang lain dan kerjasama siswa dengan orang lain baik sesama muslim atau dengan non muslim.

b. al-Quran hadits adalah penguasaan siswa Madrasah Tsanawiyah kelas VIII terhadap materi al-Qur`an Hadits.

c. Feqh adalah penguasaan siswa Madrasah Tsanawiyah kelas VIII terhadap materi Feqh.

d. Aqidah Akhlak adalah penguasaan siswa Madrasah Tsanawiyah kelas VIII terhadap materi Aqidah Akhlak.

\section{Populasi dan Sample}

Populasi penelitian ini adalah para siswa kelas VIII yang ada di MTs al-Ma`arif Singosari dan MTsN I Lawang Malang. Sedangkan teknik pengambilan sample di penelitian ini seperti yang dianjurkan Arikunto bahwa, apabila jumlah subyek kurang dari 100 orang lebih baik jumlah tersebut diambil semua, sehingga penelitiannya menjadi penelitian populasi, selanjutnya apabila jumlah subyek besar atau lebih dari 100 orang maka dapat diambil antara 10\%-15\% atau 20\%-25\% atau lebih. (Suharsimi Arikunto, 1998:120)

Berdasarkan pendapat di atas, maka pengambilan sample pada penelitian ini, peneliti mengambil jumlah 20\% dari jumlah populasi. Sample diambil dengan menggunakan metode random sampling dengan cara undian. Karena populasi penelitian ini adalah kelas II di MTs al Ma`arif dan MTsN I Lawang sebanyak 476 maka sample yang menajadi responden pada saat pengambilan data 95,2 dibulatkan menjadi 96 siswa. 


\section{Teknik Pengumpulan Data}

Pengumpulan data dilakukan dengan menggunakan; instrument angket, observasi dan dokumentasi. Angket yang akan diisi oleh responden yang menjadi sampel penelitian berupa angket tertutup dengan menggunakan model skala Likert. Sedangkan data berkenaan dengan variable mata pelajaran Aqidah Akhlak, Feqh dan al-Qur'an Hadits diperoleh melalui hasil prestasi belajar siswa.

\section{Validitas dan Reliabilitas Instrumen Penelitian.}

Agar instrument yang dipakai dalam penelitian ini dapat berfungsi dengan baik dan dapat dipertanggungjawabkan, maka instrument tersebut harus valid da reliable. Instrument dikatakan reliable bila instrument yang dibuat dapat digunakan beberapa kali untuk objek yang sama dengan hasil konsisten (Sugiono, 1999:97).

Pengujian validitas konstrak dilakukan dengan analisis item yaitu dengan mengkorelasikan item dengan skor total. Penghitungannya dilakukan dengan program SPSS for Windows. Intepretasi terhadap hasil uji validitas selanjutnya diamati pada nilai butir. Apabila nilai butir menunjukkan angka labih dari 0,168 maka butir tersebut valid dan dipakai sebagai instrument penelitian. Selanjutnya untuk menguji reliabilitas instrument maka digunakan formula koefisien Alpha dari Cronbach. Uji reliabilitas dilakukan dengan menghitung koefisien reliabilitas variable. Dalam hal ini koefisien reliabilitas dianggap handal bila lebih dari 0.6 (Arikunto, 1983,167).

Berdasarkan hasil pengujian terdapat 4 item instrument yang tidak valid, yaitu item no. 6, 13, 19 dan 20. Sedangkan reliabilitas instrument yang ada berdasarkan hasil uji lapangan didapat 0.817. Ini kalau dikonsultasikan dengan patokan yang dipegang oleh peneliti yaitu nilai reliabilitas 0.60 , maka dapat disimpulkan bahwa reliabilitas instrument ini bisa dikatakan reliabel. 


\section{Teknik Analisis Data}

Untuk memecahkan permasalahan yang ada di penelitian ini digunakan dua teknik analisis statistic, yaitu statistic deskriptif dan statistic inferensial. Statistic inferensial ini menggunakan analisa Regresi Ganda yang terlebih dahulu dilakukan uji prasyaratnya.

A. Uji Persyaratan Analisis

Sebelum analisis statistic diterapkan, maka perlu diketahui apakah data yang dikumpulkan telah memenuhi syarat untuk di analisis dengan teknik yang telah direncanakan. Mengingat penelitian yang dilakukan menggunakan analisis regresi, maka beberapa uji persyaratan analisis yang diperlukan meliputi uji normalitas, uji linieritas, dan uji multikolinieritas dan uji homosedastisitas. (Mason, 1988:452)

a. Uji normalitas data

Pengujian normalitas data dilakukan dengan chi kuadrat $\left(\mathrm{X}^{2}\right)$. Pengujian ini dilakukan dengan cara membandingkan kurva normal yang berbentuk dari data yang telah terkumpul dengan kurva normal baku. Bila kurva normal yang terbentuk dari data yang telah terkumpul tidak berbeda secara siqnifikan dengan kurva normal baku, maka data yang telah terkumpul merupakan data yang berdistribusi normal. (sugiono, 1999:79). Normalitas data akan diketahui bila harga Asymp Siqnifikan $>0,055$ pada dua ekor dan bila normal maka hasil perhitungan statistic dalam digeneralisasikan pada populasinya.

b. Uji Linieritas

Uji ini digunakan untuk mengetahui apakah hubungan antara masingmasing variable bebas dengan variable terikat bersifat linier atau tidak. Pedoman uji ini yang digunakan untuk melihat kelinieran hubungan adalah dengan mengamati devition fron linierity. Bila lajur devition from linierity menunjukkan harga $p>0,05$ berarti bahwa hubungan tersebut bersifat linier. (Nurosis, 1986)

c. Uji Multikolinieritas

Uji ini digunakan untuk mengetahui besarnya koefisien korelasi antar variable bebas. Multikolinieritas dapat dideteksi dengan menghitung koefisien korelasi ganda dan membandingkannya dengan koefisien 
korelasi antar variabel bebas. Sebagai contoh, diambil kasus regresi $\mathrm{x} 1, \mathrm{x} 2, \mathrm{x} 3, \mathrm{x} 4$ terhadap y. Pertama dihitung Ry, x1x2x3x4. Setelah itu, dihitung korelasi antar enam pasang variabel bebas, yaitu $r \times 1 \times 2$, rx1x3, rx1x4, rx2x3, rx2x4, dan rx3x4. Apabila salah satu dari koefisien korelasi itu sangat kuat, maka dilanjutkan dengan menghitung koefisien korelasi ganda dari masing-masing variabel bebas dengan 3 variabel bebas lainnya, yaitu Rx1, x2x3x4; Rx2, x1x3x4; Rx3, x1x2x4; dan Rx4, x1x2x3. Apabila beberapa koefisien korelasi tersebut mendekati Ry, x1x2x3x4, maka dikatakan terjadi multikolinieritas.

Uji multikolonieritas dengan SPSS dilakukan dengan uji regresi, dengan patokan nilai VIF (variance inflation factor) dan koefisien korelasi antar variabel bebas. Kriteria yang digunakan adalah: Pertama, jika nila VIF di sekitar angka 1 atau memiliki toerance mendekati 1, maka dikatakan tidak terdapat masalah multikolinieritas dalam model regresi; Kedua, jika koefisien korelasi antar variabel bebas kurang dari 0,5, maka tidak terdapat masalah multikolinieritas.

B. Uji Hipotesis

Pengujian hipotesis dalam penelitian ini menggunakan program SPSS for Windows. Teknik analisis untuk pengujian hipotesisi hdengan teknik regresi ganda.

\section{H. Hasil Penelitian dan Pembahasan \\ a. Pengujian Persyaratan Analisis}

Pengujian persyaratan analisis terdiri atas empat bagian yaitu uji normalitas, uji linieritas, uji multi kolinieritas dan uji homosedastisitas.

1. Uji Normalitas

Uji ini dilakukan dengan mengunakan program SPSS for Windows. Kreteria untuk menentukan normal tidaknya distribusi skor dilakukan dengan chi kuadrat. Bila hasil perhitungan menunjukkan p lebih besar dari 0,05 berarti data yang diperoleh berdistribusi normal. Hasil uji ini dapat dilihat dari table sebagai berikut: 
TABEL IHASIL UJI NORMALITAS

One-Sample Kolmogorov-Smirnov Test

\begin{tabular}{|ll|r|r|r|r|}
\hline & & \multicolumn{1}{c|}{ QurH } & \multicolumn{1}{c|}{ AqAk } & \multicolumn{1}{c|}{ Feqh } & \multicolumn{1}{c|}{ Y } \\
\hline $\mathrm{N}$ & & 96 & 96 & 96 & 96 \\
Normal Parameters(a,b) & Mean & 74.5729 & 74.7604 & 75.3542 & 72.7604 \\
& Std. Deviation & 7.99308 & 8.83622 & 8.62918 & 3.21098 \\
Most Extreme & Absolute & .091 & .081 & .073 & .128 \\
Differences & Positive & .091 & .081 & .073 & .128 \\
& Negative & & & & \\
& & -.063 & -.065 & -.057 & -.125 \\
& & & & & \\
Kolmogorov-Smirnov Z & & .895 & .793 & .716 & 1.253 \\
Asymp. Sig. (2-tailed) & & .399 & .556 & .684 & .086 \\
\hline
\end{tabular}

a Test distribution is Normal.

b Calculated from data.

Dari tabel di atas dapat disimpulkan bahwa hasil uji normalitas dari variable X1 Asymp. Siq. (2-tailed)-nya > 0,05 yaitu 0,399, X2 Asymp. Siq. (2-tailed)-nya > 0,05 yaitu 0,556, X3 Asymp. Siq. (2-tailed)-nya > 0,05 yaitu 0,684 dan variabel Y Asymp. Siq. (2-tailed)-nya di atas 0,05 yaitu 0,086. Jadi data tersebut dapat dikatakan normal.

2. Uji Linieritas

Dengan menggunakan program SPSS for Windows hasil uji linieritas yang merupakan koefisien hubungan masing-masing varibel bebas dengan variable terikat. Besarnya koefisien hubungan tersebut dapat dilihat di table sebagai berikut : 
TABEL II HASIL UJI LINIERITAS

\begin{tabular}{|l|l|l|l|}
\hline \multicolumn{2}{|l|}{ VARIABEL } & \multicolumn{1}{|l|}{} \\
\cline { 1 - 2 } Bebas & Terikat & Hasil Uji Linieritas & Penafsiran \\
\hline X1 & Y & 0.294 & Linier \\
\hline X2 & Y & 0.179 & Linier \\
\hline X3 & Y & 0.570 & Linier \\
\hline
\end{tabular}

Keterangan : X1 : Mata pelajaran al-Qur`an Hadits

X2 : Mata Pelajaran Aqidah Akhlak

X3 : Mata Pelajaran Feqh

Y : Pemahaman konsep tasamuh siswa

Dengan memperhatikan table di atas dapat diketahui bahwa semua harga uji linieritas lebih besar dari 0,05. Untuk harga deviation from Linierity dari XI sebesar 0,294, X2 harga deviation from Linierity-nya sebesar 0,179 dan X3 harga deviation from Linierity-nya sebesar 0,570. Ini berarti bahwa hubungan antar masing-masing variable bebas dan terikatnya bersifat linier.

\section{Uji Multikolinieritas}

Agar data yang diperoleh dapat dilakukan analisis lebih lanjut dengan teknik regresi, maka hubungan antar variable bebas tidak boleh terjadi multikollinieritas. Berdasarkan perhitungan dengan menggunakan program SPSS for Windows yang hasil selengkapnya terdapat di lihat dari table sebagai berikut : 
TABEL III: HASIL UJI MULTIKOLINIERITAS

Coefficient

\begin{tabular}{|c|c|c|c|}
\hline \multirow{2}{*}{ Model } & & \multicolumn{2}{|c|}{ Collinearity Statistics } \\
\hline 1 & $\mathrm{X} 1$ & Tolerance & VIF \\
\hline & $\mathrm{X} 2$ & 0.994 & 1.007 \\
\hline & $\mathrm{X} 3$ & 0.997 & 1.004 \\
\hline
\end{tabular}

a. Dependent Variabel: Y

Keterangan : X1 : Mata pelajaran al-Qur`an Hadits

X2 : Mata Pelajaran Aqidah Akhlak

X3 : Mata Pelajaran Feqh

Y : Pemahaman konsep tasamuh siswa

Ternyata nilai VIF mendekati 1 untuk semua variable bebas. Demikian pula, nilai tolerance mendekati 1 untuk semua variable bebas. Dengan demikian dapat dikatakan bahwa tidak terjadi masalah multikolinieritas, sehingga analisis regresi terdapat data yang diperoleh dapat dilaksanakan.

\section{b. Uji Hipotesis}

Hipotesis yang pertama yang perlu dibuktikan dilapangan adalah ada kontribusi yang siqnifikan antara mata pelajaran al-Qur`an Hadits terhadap pemahaman konsep tasamuh siswa. Dan hipotesisis nihilnya adalah sebaliknya.

Berdasarkan hasil perhitungan analisis regresi dengan program SPSS for Windows dapat diperoleh bahwa variable mata pelajaran al-Qur’an Hadits mempunyai kontribusi terhadap pemahaman konsep tasamuh siswa secara signifikan. Ini di buktikan dengan hasil analisis SPSS for windows dengan taraf siqnifikansi sebesar $\mathrm{p}=0,042$ dan secara parsial 
kontribusinya sebesar 4,9\%. Ini berarti hipotesis nihilnya ditolak, dan hipotesis penelitian ini diterima.

Hipotesis yang kedua yang perlu dibuktikan dilapangan adalah ada kontribusi yang siqnifikan antara mata pelajaran Aqidah Akhlak terhadap pemahaman konsep tasamuh siswa. Dan hipotesisis nihilnya adalah sebaliknya.

Berdasarkan hasil perhitungan analisis regresi dengan program SPSS for Windows dapat diperoleh bahwa variable mata pelajaran Aqidah Akhlak mempunyai kontribusi terhadap pemahaman konsep tasamuh siswa secara signifikan. Ini di buktikan dengan hasil analisis SPSS for windows dengan taraf siqnifikansi sebesar $p=0,012$ dan secara analisis parsial kontribusinya sebesar 6,9\%. Ini berarti hipotesis nihilnya ditolak, dan hipotesis penelitian ini diterima.

Hipotesis yang ketiga yang perlu dibuktikan dilapangan adalah ada kontribusi yang siqnifikan antara mata pelajaran Feqh terhadap pemahaman konsep tasamuh siswa. Dan hipotesisis nihilnya adalah sebaliknya.

Berdasarkan hasil perhitungan analisis regresi dengan program SPSS for Windows dapat diperoleh bahwa variable mata pelajaran Feqh tidak mempunyai kontribusi terhadap pemahaman konsep tasamuh siswa secara signifikan. Ini di buktikan dengan hasil analisis SPSS for windows dengan taraf siqnifikansi sebesar $\mathrm{p}=0,468$ dan secara analisis parsial kontribusinya sebesar $0,7 \%$. Ini berarti hipotesis nihilnya diterima, dan hipotesis penelitian ini ditolak.

Dari penjelasan di atas dapat ditunjukkan bahwa kontribusi ketiga variable, yaitu variable mata pelajaran al-Qur’an Hadits, Aqidah Akhlak dan Feqh secara terpisah terhadap variable pemahaman konsep tasamuh siswa dapat dilihat pada table sebagai berikut : 
Ahmad Sholeh - Pemahaman Konsep Tasamuh (Toleransi) Siswa dalam Ajaran Islam

TABEL IV: KONTRIBUSI KETIGA VARIABEL SECARA TERPISAH TERHADAP PEMAHAMAN KONSEP TASAMUH SISWA

\begin{tabular}{|ll|l|l|l|l|l|}
\hline \multirow{2}{*}{ Model } & \multicolumn{2}{|l|}{$\begin{array}{l}\text { Unstandardized } \\
\text { Coefficients }\end{array}$} & $\begin{array}{l}\text { Standardized } \\
\text { Coefficients }\end{array}$ & $\mathrm{T}$ & Sig. \\
\cline { 3 - 7 } & & $\mathrm{B}$ & Std. Error & Beta & $\mathrm{B}$ & Std. Error \\
\hline 1 & (Constant) & 61.895 & 4.833 & & 12.806 & .000 \\
& QurH & .081 & .039 & .203 & 2.061 & .042 \\
& AqAk & .091 & .036 & .250 & 2.550 & .012 \\
& Feqh & -.027 & .037 & -.072 & -.729 & .468 \\
\hline
\end{tabular}

a Dependent Variable: Y

Hipotesis ke empat dirumuskan sebagai berikut : ada kontribusi yang berarti antara mata pelajaran al-Qur`an Hadits, Aqidah Akhlak dan Feqh secara bersama-sama terhadap pemahaman konsep tasamuh siswa. Dan hipotesis nihil yang akan diuji yaitu tidak terdapat kontribusi yang berarti antara mata pelajaran al-Qur’an Hadits, Aqidah Akhlak dan Feqh secara bersama-sama terhadap pemahaman konsep tasamuh siswa secara bersama-sama.

Berdasarkan hasil perhitungan analisis regresi ganda dengan menggunakan SPSS for Windows di peroleh koefisien determinan $\mathrm{R}^{2}$ sebesar $0,117, \mathrm{p}=0,009$. Ini berarti $12 \%$ variasi variable pemahaman konsep tasamuh siswa dipengaruhi oleh mata pelajaran al-Qur’an Hadits, Aqidah Akhlak dan Feqh secara bersama-sama. Sedangkan selebihnya dipengaruhi oleh variable lain selain variable mata pelajaran al-Qur’an Hadits, Aqidah Akhlak dan Feqh. Standar kesalahan estimasi-nya adalah 3,066. Pengujian keberartian pengaruh tersebut dapat dilihat hasilnya pada table hasil analisis SPSS for windows sebagai berikut : 
TABEL V: HASIL ANALISIS REGRESI GANDA DENGAN VARIABEL X1, X2 DAN X3 TERHADAP Y

ANOVA(b)

\begin{tabular}{|ll|l|l|l|l|l|}
\hline Model & & $\begin{array}{l}\text { S u m of } \\
\text { Squares }\end{array}$ & Df & Mean Square & F & Sig. \\
\hline 1 & Regression & 114.559 & 3 & 38.186 & 4.062 & $.009(\mathrm{a})$ \\
& Residual & 864.931 & 92 & 9.401 & & \\
& Total & 979.490 & 95 & & & \\
\hline
\end{tabular}

a Predictors: (Constant), Feqh, AqAk, QurH

b Dependent Variable: $Y$

Ket: $\quad \mathrm{X} 1=$ mata pelajaran al-Qur'an Hadits

$\mathrm{X} 2$ = Aqidah Akhlak

$\mathrm{X} 3=$ Feqh

$\mathrm{Y}=$ Pemahaman konsep tasamuh siswa dalam Islam

Berdasarkan table di atas di peroleh harga $F=4,062$ dengan harga sebesar $p=0,009$. Oleh karena nilai $p<0,05$. Ini berarti hipotesis nihil di tolak dan hipotesis penelitian diterima. Hal ini dikarenakan ada ketentuan penerimaan dan penolakan terjadi jika siqnifikansi dibawah atau sama dengan 0,05, maka Ha diterima dan Ho ditolak. Dengan demikian dapat disimpulkan bahwa antara mata pelajaran al-Qur`an Hadits, Aqidah Akhlak dan Feqh secara bersama-sama memberikan kontribusi yang nyata terhadap pemahaman konsep tasamuh siswa.

Berdasarkan analisis regresi ganda yang dilakukan oleh peneliti di dapatkan antara variable bebas dan terikat diketahui pula harga konstan regresi sebesar 61,895 , harga koefisien beta variable $\mathrm{X} 1=0,081$, harga koefisien beta variable X2 $=0,091$ dan harga koefisien beta variable X3 $=-0,027$. Sehingga persamaan regresi linier yang diperoleh dari hasil analisis tersebut sebagai berikut:

$$
\mathrm{Y}=61,895+0,081 \mathrm{X} 1+0,091 \mathrm{X} 2-0,027 \mathrm{X} 3
$$

Di samping itu diketahui kesalahan regresi sebesar 4,833 untuk beta 0. Untuk standar kesalahan persamaan regresi untuk X1 sebesar 0,039, 
Untuk standar kesalahan persamaan regresi untuk X2 sebesar 0,036, dan Untuk standar kesalahan persamaan regresi untuk X3 sebesar 0,037.

\section{c. Pembahasan Hasil Penelitian}

A. Kontribusi Mata Pelajaran Al-Qur`an Hadits terhadap pemahaman konsep Tasamuh siswa

Dalam tradisi Islam, toleransi (tasamuh) biasa dipadankan dengan istilah 'tasahul wa tasamuh'. Tasahul berarti mempermudah atau bersikap lembut dan ramah dengan yang lain. Sementara tasamuh berarti memaafkan. Sesuai dengan ajaran al-Quran dan hadis, di satu sisi Islam merupakan ajaran agama yang mudah diterapkan. Sedang di sisi lain, Islam menghendaki keramahan dan sikap pemaaf. Dalam salah satu hadisnya yang terkenal, Rasulullah Saw bersabda, "Allah Swt tidak mengutusku untuk (mengajarkan) tentang mengasingkan diri dan kerahiban. Tapi mengutusku untuk membawa agama yang suci, mudah, dan pemaaf".

Mengomentari masalah itu, filosof kontemporer Iran, Syahid Muthahhari menuturkan, "Islam sebagaimana yang dituturkan oleh Rasulullah saw merupakan agama yang pemaaf dan mudah. Dalam syariat ini, lantaran sifatnya yang mudah itulah, maka Allah tidak mengeluarkan kewajiban yang sulit. (Sebagaimana firman Allah Swt dalam al-Quran) Allah tidak menetapkan hal yang menyulitkan dalam agamanya. Dan lantaran sifat Islam yang pemaaf, maka setiap kewajiban yang sulit dilaksanakan, akan dibebaskan". Dengan demikian menurut Islam, secara teoritis dan praktis maupun etis, toleransi merupakan hal yang dibenarkan. Tentu saja, toleransi yang diterapkan itu mesti berlandaskan pada prinsip dan nilai-nilai Islam serta sesuai dengan maslahat umat.

Salah satu contoh dari toleransi yang diajarkan Islam adalah berlaku ramah dengan masyarakat. Masalah itu telah berkali-kali ditekankan oleh Islam, sebagaimana yang disabdakan Rasulullah saw. Beliau bersabda, "Hidup bermasyarakat dengan ramah merupakan separuh iman. Dan bersikap lemah lembut dengan mereka merupakan separuh kehidupan".

Imam Ali as juga meyakini bahwa keselamatan di dunia dan akhirat ditentukan oleh sikap ramah seseorang dalam bermasyarakat. Perjalanan 
hidup Rasulullah saw dan para Ahlul Baitnya as juga menunjukkan sikap mereka yang selalu diwarnai dengan kasih sayang dan pemaaf. Sikap semacam itu tidak hanya mereka terapkan di kalangan masyarakat muslim semata tapi juga di kalangan non-muslim. Terkait hal ini, Ayatollah Syahid Muthahhari menulis, "Islam menginginkan kita supaya berlaku baik terhadap semua orang, bahkan pada terhadap orang-orang kafir sekalipun. Kepada sekelompok orang-orang kafir, Rasulullah saw berkata, 'Hati ku sedih melihat kalian. Mengapa kalian tidak sampai pada kebaikan dan hak yang mesti kalian peroleh'. Sejatinya, Rasulullah Saw menjadi begitu cemas dan sedih lantaran orang-orang kafir tidak bisa memahami kebenaran dan melangkah di jalan yang benar. Sebegitu sedihnya Rasulullah saw melihat kondisi mereka hingga Allah Swt dalam surat al-Kahfi, ayat 6 berfirman:

"Maka (apakah) barangkali kamu akan membunuh dirimu karena bersedih hati setelah mereka berpaling, Sekiranya mereka tidak beriman kepada keterangan ini (al-Quran)".

Mata pelajaran al-Quran Hadits dilaksanakan disekolah sebagai wahana untuk pedoman siswa untuk menjalankan dan melestarikan nilai-nilai luhur ajaran Islam yang ada seperti di atas dalam kehidupan sehari-hari. Perilaku siswa yang diharapkan setelah menempuh pelajaran al-Qur’an Hadits adalah perilaku yang memancarkan iman dan taqwa kepada Allah SWT dalam masyarakat yang terdiri dari berbagai agama dan perilaku kemanusiaan lainnya. Oleh karena itulah dalam mata pelajaran al-Qur’an Hadits ini diajarkan nilai-nilai toleransi/tasamuh dalam Islam.

Berdasarkan hasil perhitungan analisis regresi dengan program SPSS for Windows dapat diperoleh bahwa variable mata pelajaran al-Qur`an Hadits mempunyai kontribusi terhadap pemahaman konsep tasamuh siswa secara signifikan. Ini di buktikan dengan hasil analisis SPSS for windows dengan taraf siqnifikansi sebesar $p=0,042$ dan secara parsial kontribusinya sebesar 4,9\%.

Hasil di atas membuktikan bahwa melalui mata pelajaran al-Qur’an Hadits dapat dikembangkan pemahaman dan sikap tasamuh siswa baik antar sesama maupun dengan sesama muslim. 
B. Kontribusi Mata Pelajaran Aqidah Akhlak terhadap pemahaman konsep Tasamuh siswa

Mata Pelajaran Aqidah Akhlak diberikan kepada siswa diharapkan siswa mampu mengajahwentahkan nilai-nilai ajaran Islam dalam masyarakat majemuk/prural. Dan siswa mampu bersikap dan menghargai terhadap kemajemukan tersebut sehingga tidak ada konflik antar agama maupun dengan sesama muslim. Hal ini dikarenakan didalam mata pelajaran ini di kembangkan rasa solidaritas tarhadap sesame di dalam masyarakat.

Di Madrasah Tsanawiyah pendidikan Aqidah Akhlak merupakan bagian integral dari pendidikan agama. Memang pendidikan Aqidah Akhlak bukan satu-satunya faktor yang menentukan sekaligus membentuk watak dan kepribadian peserta didik. Tetapi secara substansial mata pelajaran Aqidah Akhlak memiliki kontribusi dalam memberikan motivasi kepada peserta didik untuk mempraktikkan nilai-nilai keyakinan keagamaan (tauhid) dan akhlakul karimah dalam kehidupan sehari-hari.

Pendidikan Aqidah Akhlak memberikan pengajaran tentang tata nilai yang mengatur hubungan antara manusia dengan Tuhan, mengatur hubungan antara sesama manusia, mengatur hubungan dengan lingkungan dan mengatur dirinya sendiri. Dengan demikian pelajaran Aqidah Akhlak merupakan pelajaran yang teoritis dan aplikatif. Pelajaran teoritis menanamkan ilmu pengetahuan, sedangkan pelajaran aplikatif membentuk sikap dan perilaku dalam kehidupan. Jadi, tolok ukur keberhasilan siswa tidak dapat diukur dengan tinggi rendahnya taraf intelektual anak (aspek kognitif), melainkan hendaknya harus dilihat dari sisi bagaimana karakteristik yang terbentuk melalui pendidikan formalnya (aspek afektif dan psikomotorik).

Upaya pengembangan pembelajaran Aqidah Akhlak yang berorientasi pada pendidikan nilai (afektif) perlu mempertimbangkan 3 faktor yang mempengaruhi pembelajaran Pendidikan Agama Islam (PAI), yang lebih menekankan pada penggalian karakteristik peserta didik, terutama dalam hal perkembangan nilai yang sekaligus dapat mempengaruhi pilihan strategi (pendekatan metode dan teknik) yang dikembangkannya. Sehingga pembelajaran Aqidah Akhlak tidak sekedar terkonsentrasi pada persoalan teoritis dan kognitif semata, akan tetapi juga sekaligus mampu menginternalisasikan makna dan nilai-nilai Aqidah Akhlak dalam diri 
siswa melalui berbagai cara, media dan forum. Selanjutnya makna dan nilai-nilai tersebut dapat menjadi sumber motivasi bagi siswa untuk bergerak, berbuat, berperilaku secara konkrit dalam wilayah kehidupan praktis sehari-hari.

Karena itu sekolah, yang berfungsi sebagai wahana pembinaan, pengajaran dan pendidikan harus mampu mengatasi perilaku siswa dengan menggunakan mata pelajaran Aqidah Akhlak sebagai materi pokoknya dengan menginternalisasikan ke dalam diri siswa makna dan nilai-nilai Aqidah Akhlak dalam interaksi riil agar dapat tercapai tujuan pendidikan yaitu menciptakan manusia Indonesia seutuhnya serta menjauhkan diri siswa dari penyimpangan perilaku yang tidak diharapkan.

Berdasarkan hasil perhitungan analisis regresi dengan program SPSS for Windows dapat diperoleh bahwa variable mata pelajaran Aqidah Akhlak mempunyai kontribusi terhadap pemahaman konsep tasamuh siswa secara signifikan. Ini dibuktikan dengan hasil analisis SPSS for windows dengan taraf siqnifikansi sebesar $p=0,012$ dan secara parsial kontribusinya sebesar 6,9\%. Ini berarti hipotesis nihilnya ditolak, dan hipotesis penelitian ini diterima.

Hasil di atas membuktikan bahwa mata pelajaran Aqidah Akhlak ikut mempunyai sumbangan yang siqnifikan terhadap penanaman konsep tasamuh terhadap siswa memalui pengenalan prinsip-prinsip bagaimana berperilaku dalam kenyataan hidup dalam keberagaman beragama, untuk dapat mewujudkan prinsip bahwa Islam itu rahmatal lil-alamin.

C. Kontribusi Mata Pelajaran Fiqh terhadap pemahaman konsep Tasamuh siswa

Mata Feqh dilakukan di sekolah dengan harapan siswa mengetahui dasar dan mampu bertindak sesuai syari at Allah SWT dalam kehidupan sehari-hari. Karena mata pelajaran ini diberikan bertujuan untuk membekali peserta didik agar dapat: Pertama, mengetahui dan memahami pokokpokok hukum Islam secara terperinci dan menyeluruh, baik berupa dalil naqli dan aqli. Pengetahuan dan pemahaman tersebut diharapkan menjadi pedoman hidup dalam kehidupan dan sosial. Kedua, Melaksanakan dan mengamalkan ketentuan hukum Islam dengan benar. Pengalaman tersebut 
diharapkan menumbuhkan ketaatan menjalankan hukum Islam, disiplin dan tanggung jawab sosial yang tinggi dalam kehidupan pribadi maupun sosial.

Namun setelah di analisis data yang didapat dilapangan didapatkan bahwa variable mata pelajaran Feqh tidak mempunyai kontribusi terhadap pemahaman konsep tasamuh siswa secara signifikan. Ini di buktikan dengan hasil analisis SPSS for windows dengan taraf siqnifikansi sebesar $p=0,468$ dan secara parsial kontribusinya 0,7\%. Ini berarti hipotesis nihilnya diterima, dan hipotesis penelitian ini ditolak.

Dalam pandangan peneliti kemungkinan besar bahwa dalam proses pembelajaran Feqh selama ini belum menyentuh pembekalan terhadap kemampuan siswa untuk bisa melatih dalam menerapkan ajaran tasamuh kepada siswa. Kenyataan ini sesuai dengan apa yang dikatakan Madjid, (1997:141) bahwa pengajaran agama disekolah dan madrasah umumnya didominasi oleh orientasi lahiriyah, Feqh dan kalam, yaitu segi-segi eksoteris. Oleh karenanya anak didik hanya faham tentang rukun dan syarat sholat bukan kepada untuk mengetahui apa makna sesungguhnya sholat bagi pembentukan karakter seseorang. Kurang diajarkannya berbagai macam pendapat dalam masalah furuiyah sehingga hanya menimbulkan fanatisme yang berlebihan dan mengakibatkan kurangnya sikap toleran (tasamuh) dalam kehidupan bersama. Akibatnya siswa mempnyai sikap fanatisme secara tidak proposional. Disamping itu, dalam kehidupan beragama tidak mengenal berbagai perbedaan furu iyah dalam menjalankan ibadah baik ibadah dalam pengertian khusus maupun dalam pengertian umum dalam menjalankan syariat Islam.

\section{H. Kesimpulan}

Dari uraian yang ada dengan merujuk pada sumber data dan pembahasan, maka hasil penelitian ini dapat ditarik suatu kesimpulan dengan menjawab permasalahan focus dalam penelitian ini, yaitu :

1. Variable mata pelajaran al-Qur’an Hadits mempunyai kontribusi terhadap pemahaman konsep tasamuh siswa secara signifikan. Ini di buktikan dengan hasil analisis SPSS for windows dengan taraf siqnifikansi sebesar $\mathrm{p}=0,042$ dan secara analisis parsial kontribusinya 
sebesar $4,9 \%$.

2. Variable mata pelajaran Aqidah Akhlak mempunyai kontribusi terhadap pemahaman konsep tasamuh siswa secara signifikan. Ini di buktikan dengan hasil analisis SPSS for windows dengan taraf siqnifikansi sebesar $\mathrm{p}=0,012$ dan secara analisis parsial kontribusinya sebesar $6,9 \%$.

3. Variable mata pelajaran Feqh tidak mempunyai kontribusi terhadap pemahaman konsep tasamuh siswa secara signifikan. Ini di buktikan dengan hasil analisis SPSS for windows dengan taraf siqnifikansi sebesar $\mathrm{p}=0,468$ dan secara analisis parsial kontribusinya sebesar $0,7 \%$.

4. Berdasarkan hasil perhitungan analisis regresi ganda dengan menggunakan SPSS for Windows di peroleh koefisien determinan $\mathrm{R}^{2}$ sebesar $0,117, \mathrm{p}=0,009$. Ini berarti $12 \%$ variasi variable pemahaman konsep tasamuh siswa dipengaruhi oleh mata pelajaran al-Qur`an Hadits, Aqidah Akhlak dan Feqh secara bersama-sama. Sedangkan selebihnya dipengaruhi oleh variable lain selain variable mata pelajaran al-Qur`an Hadits, Aqidah Akhlak dan Feqh. Dan standar kesalahan estimasi-nya adalah 3,066.

\section{Saran-saran}

Dengan mempertimbangkan hasil penelitian ini maka peneliti perlu memberikan saran-saran sebagai berikut :

a. Para guru agama Islam di lingkungan Madrasah Tsanawiyah secara umum haruslah meningkatkan lagi proses pembelajaran al-Qur`an Hadits, Aqidah Akhlak dan Feqh guna untuk proses perbaikan mutu pendidikan Islam yang ada.

b. Masih perlu adanya kesadaran oleh siswa untuk meningkatkan lagi pemahamannya terhadap konsep tasamuh dalam Islam. Dengan harapan lebih lanjut siswa dapat mengaplikasikan perwujudan nyata tentang konsep tasamuh dalam kehidupan secara pribadi maupun bersosial. 


\section{DAFTAR PUSTAKA}

Arikunto, Suharsimi, Prosedur Penelitian, Bina Aksara, Jakarta,1983.

Awat, Napa J., Metode Statistik dan Ekonometri, Liberty, Yogyakarta, 1995.

Dr. M. Quraish Syihab, Wawasan Al-Qur'an Tafsir maudhu'I atas Pelbagai Persoalan Umat.Mizan, Jakarta, 1997.

Departemen Agama RI, Pedoman Khusus Aqidah Akhlak Madrasah Tsanawiyah, Jakarta: Dirjen Kelembagaan Agama Islam, 2004.

Departemen Agama RI, Standar KOmpetensi Madrasah Tsanawiyah ,Jakarta: 1994

Fahmi Salim, Membincang Toleransi dalam PerspektifAl-Qur'an[1], Makalah disampaikan dalam acara seminar dan bedah buku "Al-Qur'an Kitab Toleransi”, karya sdr. Zuhairi Misrawi, Lc. Penerbit: Fitrah, 2007. yang diselenggarakan oleh Program Pasca-Sarjana Kelas Internasional PTIQ-Jakarta pada hari Kamis, 3 April 2008.

Madjid, Masyarakat Religiuos, Paramadina, Jakarta, 1997.

Romli Arief, Kuliah Pendidikan Agama Islam, IKIP Surabaya, Surabaya:tt.

Ridwan Rustandi, Konsep Tasamuh Dalam Dimensi Kehidupan Beragama, http://namestic.wordpress.com/2011/03/17/konsep-tasamuhdalam-dimensi-kehidupan-beragama-oleh-ridwan-rustandi/, diambil pada tanggal 18 April 2011 jam 09.00.

Suharsimi Arikunto, Prosedur Penelitian Suatu Pendekatan Praktek, Rineka Cipta, Jakarta,1998.

Sugiyono, Statistik Penelitian, Alfabeta, Bandung, 2002.

Sugiyono, Statistika untuk penelitian, Alfabeta, Bandung, 1997.

Sugiyono, Metode Penelitian Bisnis, Alfabeta, Jakarta,1999.

Sutrisno Hadi, Metodologi Riset, Fakultas Psikologi UGM, Yogyakarta, 1986.

Usa, Muslih dan Widjan, Aden (peny), Pendidikan Islam dalam Peradaban Industrial, Aditya Media, Yogyakarta, 1997.

Yuhanar Ilyas, Kuliah Aqidah Islam, LPPI, Yogyakarta, 1992.

Zahruddin AR, dan Hasanuddin Sinaga, Pengantar Studi Akhlak, Raja Grafindo Persada, Jakarta, 2004. 